\title{
P O
}

Th I A G O M A T OS

\section{2,1}

eu estava na minha cabeça

me imaginando

falando numa entrevista

(como me imagino sempre)

de quando proust

desmaiou

vendo o quadro (um quadro de alguém)

"ele era doente", eu diria,

"ele era fisicamente doente,

desmaiou porque teve talvez

uma emoção forte

e como era frágil...

mas não desmaiou por causa do quadro

a arte ainda não tem

ou não tem mais

o poder de

fazer as pessoas desmaiarem"

e aí

em seguida

imediatamente

pensei numa

máquina

que era uma luva de boxe com um braço

mecânico

retraído que se expandia e dava um soco

no espectador

quando ele chegava perto

e o espectador desmaiava

ou

se fosse inteligente

pelo menos

fingia

desmaiar

\section{3,8}

vou escrever tantos poemas quantos me forem permitidos serem escritos

poemas

poesia, reza uma ave-maria

teu problema, poesia, é não rezar

(antes de dormir)

uma ave-maria

hoje à tarde voltei da rua

(estraçalhado pela rua)

e ouvindo música

levantei até a metade os braços

(como se fossem asas)

e como se meus braços fossem asas comecei a ir pouco a pouco

(devagar)

levantando e abaixando

(um pouquinho)

até que eu batia as asas rápido e fazendo força

e olhando meu reflexo

na televisão desligada e

pensei em algo que aqui não posso escrever

não lembro o que pensei

Thiago Mattos nasceu em Petrópolis, Rio de Janeiro, e estudou cinema e letras na Universidade Federal Fluminense. Atualmente éprofessor de francês e tradutor. Tem poemas publicados em revistas virtuais. Seu primeiro livro de poemas, Teu pai com uma pistola, foi lançado em 2012-2013, tendo recebido boa acolhida no meio literário, sendo resenhado por José Castello, pela revista Cult etc. 